\title{
Políticas del montaje. IMAGEN Y MEMORIA EN LA ARgentina
}

Politics of Montage. Image and Memory in Argentina

\section{Luis Ignacio García \\ Consejo Nacional de Investigaciones Científicas (CONICET) - Universidad Nacional de Córdoba (Argentina)}

RESUMEN: Se aborda aquí la pregunta por las tensiones entre imagen y memoria en la Argentina. Para ello se analizan tres ensayos fotográficos que guardan entre sí profundas afinidades estético-políticas. En ellos se puede plantear una productiva intersección entre cierto estado de la memoria y ciertos debates sobre la representación visual del pasado dictatorial y su desmesura de muertes. En ambos registros, las obras seleccionadas confluyen en su estrategia radical de montaje: montaje visual que activa una crítica de la representación y propone la creación de acontecimientos visuales para pensar la historia; montaje histórico que propone un desarreglo temporal orientado críticamente contra todas las formas de historicismo con que la militancia tradicional se desentendió del lado oscuro de su propia acción. Una política de la imagen y una política del tiempo de una generación en la que se anuncian las matrices de nuevas formas de lo político.

PalAbras clave: memoria, imagen, montaje, fotografía, desaparición.

RESUM: En aquest article s'aborda la pregunta per les tensions entre imatge i memòria a l'Argentina. A l'efecte, s'hi analitzen tres assaigs fotogràfics que guarden entre si profundes afinitats esteticopolítiques. En aquests es pot plantejar una productiva intersecció entre cert estat de la memòria i certs debats sobre la representació visual del passat dictatorial i la seua desmesura de morts. En ambdós registres, les obres seleccionades conflueixen en una estratègia radical de muntatge: muntatge visual que activa una crítica de la representació i proposa la creació d'esdeveniments visuals per a pensar la història; muntatge històric que proposa un desarranjament temporal orientat críticament contra totes les formes d'historicisme amb què la militància tradicional 
es va desentendre de la part fosca de la seua pròpia acció. Una política de la imatge i una política del temps d'una generació en què s'anuncien les matrius de noves formes de la política.

Paraules Clau: memòria, imatge, muntatge, fotografia, desaparició.

ABSTRACT: This paper addresses the tensions between image and memory in Argentina. To this end it discusses three photographic essays with deep affinities that pose a productive intersection between a certain history of memory and certain debates on the visual representation of the dictatorial past. At both levels, the selected photographic works converge in their radical montage strategy: visual montage that activates a critique of representation and proposes the creation of visual events to think about history; historical montage that poses a temporal disorder critically orientated against all forms of historicism with which the traditional militancy disregarded the dark side of its own actions. A politics of image and a politics of time from a generation in which the matrices of new political forms are announced.

KEYWORDS: memory, image, montage, photography, disappearance. 
Los recuerdos son mares inabarcables. Tomo fotos como pequeños fragmentos arbitrarios que arrebato al tiempo. Con esos fragmentos construyo y cuento el tiempo imaginado, creado. Rearmo como en el agua, de a oleadas, un gran rompecabezas.

\section{Lucila Quieto}

\section{Encuadre}

Q e propone aquí un abordaje fragmentario de la pregunta por las tensiones entre imagen y memoria en la Argentina. Para ello se analizarán tres ensayos fotográficos que guardan entre sí profundas afinidades estético-políticas. La selección de las obras respondió al modo en que a partir de ellas se puede plantear una productiva intersección entre dos de los debates más álgidos sobre el pasado reciente en la Argentina. Uno, referido al itinerario de un cierto estado de la memoria, es decir, a una historia de los momentos hegemónicos de la memoria en la Argentina de la posdictadura. Otro, ligado al problema de la imagen, y más en general, de la representación visual del pasado dictatorial y su desmesura de muertes. En ambos registros, las obras aquí seleccionadas ocupan una posición de avanzada.

En cuanto al primer registro de discusiones, hay cierto consenso en reconocer, en términos generales, tres grandes momentos de la memoria en la Argentina a partir de $1983 .{ }^{1}$ El primer momento es el de la inmediatez posdictatorial, en el que la proximidad del horror condujo a la convivencia de políticas de reparación junto a estrategias exculpatorias y denegatorias. El meritorio juicio a las juntas militares judicializó una memoria que pretendía tramitar en sede tribunalicia un desquiciamiento social de alcances catastróficos. El sujeto de esta memoria fue una «sociedad civil» que lavó sus culpas en la teoría de los dos demonios, y se reflejó en la imagen de un desaparecido convertido en víctima impoluta, tan víctima y tan impoluta como la sociedad que la construyó. Una segunda etapa, que suele ser ubicada alrededor de mediados de los años 90, buscó reponer el espesor histórico y político de los desaparecidos y de su generación. Reaparecieron viejas banderas y se suscitó un importante desplie-

1. Véase, entre otros, Kaufman, 2005; Casullo, 2009; Pittaluga, 2007; Oberti y Pittaluga, 2006; García, 2008. 
gue de producciones documentales, periodísticas, cinematográficas, muchas de las cuales intentaban restituir ficcionalmente el calor setentista en los helados 90 neoliberales. Sin embargo, el resultado muchas veces fue una mera inversión del momento anterior: frente al desaparecido como víctima inmaculada en cuya imagen exculpatoria se pretendía reflejar una sociedad acorralada, aparece la figura del desaparecido como héroe igualmente inmaculado en el que se espejaba un conjunto de ex militantes con escasa capacidad autocrítica. Por último, un tercer momento, desde fines de los 90, estaría signado por dos rasgos fundamentales: la aparición decidida de la voz de los hijos, y el inicio de la problematización de la cuestión de la memoria en cuanto tal. Para decirlo con Nicolás Casullo, «en el presente se asiste a una etapa signada por propuestas documentales y ficcionales donde se cruzan distintas vivencias de relatos generacionales y de hijos de desaparecidos en disputa de versiones, a la vez que se abrió una discusión ya no sólo sobre lo acontecido, sino sobre lo que se puede denominar la historia de las narraciones de la memoria de los 70» (Casullo 2009, p. 13). En esta tercera etapa la generación que no vivió los 70 comienza a hacer oír su voz, a la vez que empieza a reconocerse una suerte de bucle reflexivo de la memoria sobre sus propias condiciones, aporías y posibilidades. Como veremos, las fotos que proponemos se inscriben en esta última estación de la memoria en la Argentina, por ostentar ambos rasgos: una voz generacionalmente renovadora y una tematización metarreflexiva sobre la propia memoria.

En cuanto al segundo registro de discusiones, esto es, el problema de la representación visual del pasado reciente, los consensos son menos sólidos, las perspectivas menos nítidas, aunque son muchas las voces que ya se han hecho oír. ${ }^{2}$ Podría sugerirse que las posturas se tensan en el arco descrito de modo paradigmático y modélico en el debate suscitado en Francia a partir de la muestra Memoir de camps, en París el año 2001. ${ }^{3}$ Como se sabe, el catálogo que Georges Didi-Huberman escribiera para cuatro fotografías sacadas por el Sonderkommando de un campo de concentración suscitó una dura respuesta polémica de dos intelectuales próximos a Claude Lanz-

2. Véanse, entre otros: Brodsky, 2005; Jelin y Longoni, 2005; Lorenzano y Buchenhorst, 2007; Blejmar, Fortuny y García, 2013.

3. Intenté un cruce entre este debate y los debates argentinos en García 2009. 
mann. Frente al optimismo visual de Didi-Huberman, estos críticos sostenían el mandato ético de la «irrepresentabilidad» de la Shoá, como garantía contra la profanación fetichista, visual y mercantil de la memoria de los muertos. Sin pretender reponer aquí la complejidad de este debate, puede destacarse que tuvo la virtud de polarizar el campo de discusión en sus extremos, y plantear las aporías del debate acerca de la «representación de lo irrepresentable». La polémica pareciera jugarse entre la exigencia de ver para saber — bajo el riesgo de una recaída en el orden fetichista-mercantil de la contemporánea cultura de la imagen - y el reclamo, de fondo bíblico, de la prohibición de las imágenes en favor de la memoria por la palabra - bajo el riesgo de una recaída en un simple negarse a ver- . Didi-Huberman, en un conocido libro en el que incluye el polémico catálogo y una amplia serie de respuestas a sus objetores (Didi-Huberman 2004), sugiere una salida de la dicotomía, un más allá de las aporías del debate que opone de manera maniquea y polar representación/irrepresentable, imagen/palabra, un más allá de la falsa tensión entre la imagen-fetiche, que pretende mercantil y obscenamente mostrarlo todo, y la imagen-tabú, que en el extremo de su observancia ética parece próximo a la culminación misma del exterminio en el borramiento de sus huellas. En sintonía con otros autores contemporáneos disímiles como Jacques Rancière, Giorgio Agamben, o Jean-Luc Nancy, Didi-Huberman nos propone un desplazamiento: abandonar el «uso inflacionista de la noción de irrepresentable» y transformar el problema ético-religioso de «la imposibilidad de la representación» en el problema estético-político de la «regulación de la distancia representativa» (Didi-Huberman, 2004, p. 229). Didi-Huberman plantea este desplazamiento del problema desde un rescate de lo que denomina la tradición del montaje. Los defensores de una ascética de la representación buscan mostrar sólo la imposibilidad de representar, mostrar esa nada, ese vacío. El montaje sería la representación que resta en lo imaginario cuando se ha asumido su sustracción constitutiva. Tras la explosión de un orden de la visión, el montaje sería el registro caótico de sus esquirlas en diseminación. Ni la transparencia aproblemática de la representación y su imagen-fetiche, ni el atolladero del mandato mosaico y su imagen-tabú, sino el gesto reflexivo de una imagen que pone en escena sus propias condiciones de posibilidad, de una imagen que parte del fragmento desfigurado para construir desde allí un sentido. 
Las obras seleccionadas se inscriben en esta doble coyuntura de problemas, y de una manera privilegiada. Pues a la vez que una serie de rasgos permiten inscribirlas como ejemplos del más reciente estadio de la memoria antes descripto, sus planteamientos formales nos permiten ubicarlas en la salida sugerida por Didi-Huberman y otros a la aporética de la representación.

Los artistas seleccionados forman parte de la generación de los hijos de los protagonistas de aquellos años, y las obras que mostraremos fueron realizadas entre 1999 y 2007. Se trata de obras emplazadas en el terreno de lo que Marienne Hirsch nombró con el concepto de «posmemoria» (Hirsch 1997), esto es, la memoria de los no protagonistas, una memoria de segunda generación, de aquellos a quienes los acontecimientos les llegan a través de la mediación de relatos que los preexisten, y que por tanto guardan una verdad singular, nunca idéntica a la verdad de los participantes sobrevivientes. Estos artistas, todos familiares de desaparecidos, trabajan con las piezas de un rompecabezas colectivo, que apunta a una intervención renovadora en las polémicas por la memoria en la Argentina, con sus rasgos, temas y formas propios.

Ello nos conduce a las afinidades formales que permiten justificar este recorte. En primer lugar, se puede señalar cierto gesto modernista de dislocamiento o desdoblamiento reflexivo. En muchos casos se trata de fotos de fotos, o bien de conjuntos elaborados a partir de fotos, de las que se explicita, además, su estatuto fotográfico. Estas imágenes son inescindiblemente una reflexión acerca de las imágenes. Como decía Casullo, la memoria comienza a reflexionar acerca de sí misma. Reflexividad de la imagen que, con Didi-Huberman, llamamos con el viejo nombre del montaje. En todos estos trabajos encontramos gestos de desdoblamiento, de duplicación siniestra o de mediación, en los que podemos leer una insistente resistencia a toda aspiración de falsa unidad, reconciliación o identidad, en la imagen y en la memoria colectiva.

En segundo lugar, la singularidad estético-política de estas fotos radica justamente en el modo en que saben conectar estos trayectos de la memoria y de la imagen. En ellas, una voz renovadora de la memoria, tan lejos de la memoria del «Nunca más» como de la épica heroica de los ex-militantes, se abre gracias al desarreglo de la temporalidad y de la imagen operado por sus estrategias de montaje. 


\section{Arqueologías}

Arqueología de la ausencia 4 es un ensayo fotográfico que surge a partir de una falta. Lucila Quieto, nacida en Buenos Aires en 1977 y cofundadora de la agrupación HIJos, llega a estas imágenes a partir del deseo de esa foto inexistente e imposible con su padre desaparecido. ${ }^{5}$ Carlos Alberto Quieto, militante montonero en los años 70, desapareció cinco meses antes de que naciera su hija Lucila. Después de distintas búsquedas y experimentos, Lucila llegó al dispositivo anamnésico de estas fotos: escaneó las fotografías de su padre y las proyectó ampliadas sobre la pared, interponiendo su propio cuerpo entre el proyector y la pared. La fotografía resultante, en blanco y negro, muestra, en una misma foto imposible, y por primera vez, su imagen junto a la de su padre.

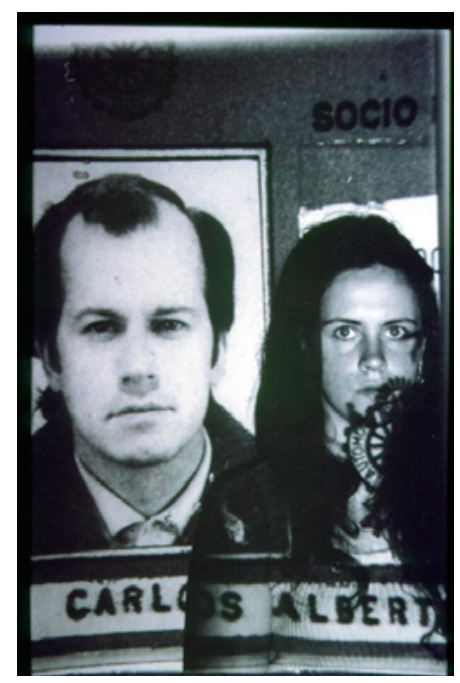

\section{Imagen 1}

Luego, invitó a otros hijos de desaparecidos a hacer lo mismo, a través de carteles que decían, con un dejo de ironía publicitaria: «Ahora podés tener la foto que siempre quisiste». Así, Lucila puso un procedimiento a disposición

4. Se puede visualizar en la web: http://es.slideshare.net/lalunaesmilugar/arqueologia-de-laausencia.

5. Sobre este ensayo en particular se han ofrecido ya varias lecturas de las que me declaro deudor: Blejmar, 2009; Longoni, 2011; Fortuny, 2009; Amado, 2009. 
de un proceso ahora ya colectivo, que expande por tanto sus sentidos, pues la fotógrafa deja que el retratado intervenga activamente en el proceso de construcción de la nueva imagen, eligiendo la foto que se proyectará, la posición que adoptarán los fotografiados, los gestos, el juego de las miradas, etc. Entre 1999 y 2001 produjo un total de 35 «historias» (así las nombra ella) de hijos e hijas de desaparecidos fotografiados con sus padres y madres.

Una serie de una extraña y singular belleza, a pesar de ser éste un atributo que no se suele pedir a imágenes de este tipo (e incluso, en algunos casos, se rechazaría como blasfemo). El tono de este poderoso ensayo es entre poético y ritual. Antes que nada, parece remitirnos a un acto de restitución. Restitución de una imagen inexistente, de un encuentro imposible. Cierto tono de recogimiento, gestos relajados, por momentos alegres y divertidos, los ojos a veces cerrados, algunos torsos desnudos que acentúan el deseo de contacto con la imagen proyectada, parecen remitir a la experiencia de una adeudada y esperada reparación. Se construye un súbito aquí y ahora de fuerte carga aurática en el que la superposición tramada en los propios cuerpos guarda la promesa materialista de una redención táctil. Estas imágenes parecen ofrecer no sólo el fugaz encuentro entre un presente en duelo y un pasado perdido, sino que además, en el osado gesto de poner el cuerpo como pantalla o soporte de las proyecciones del pasado, parecen cumplir el complejo ritual de ofrecer el propio cuerpo como inscripción posible para un cuerpo ausente, como sustituto de la tumba que no fue.

Sin embargo, este deseo de reconciliación no deja de mostrar explícitamente sus límites e imposibilidades. Podemos reconocer en estas fotos aquello que enunciábamos al principio para esta nueva etapa de la memoria: la necesidad del diálogo con la generación de los «padres» convive dramáticamente con la expresión de una brecha insalvable. Y esa oscilación se expresa en la singular ambigüedad crítica de estas imágenes. Diálogo y brecha, identificación y dislocación, estas imágenes rituales y poéticas rozan sin embargo el hostil espacio de lo siniestro. Desde su poética restitutiva, lanzan con violencia crítica un grito destemplado por una llaga que no logra suturarse pese a la intención reparadora de estas fotos, ya que en ellas no se busca borrar las marcas de la dislocación. En términos formales, no se ocultan las huellas del montaje, del procedimiento, sino que se subraya el carácter arti- 
ficial, ficcional, de la imagen resultante. La sutileza poética con que se logra esta ostensión del dispositivo está entre las condiciones de la belleza de estas imágenes. Las marcas de los documentos de donde fueron extraídas las fotos, los bordes irregulares, los dobleces, los pliegues, las roturas o rajaduras de las viejas fotografías, a veces incluso remendadas con una brutal cinta adhesiva, todas estas marcas no se limpian, y cumplen una función en la economía de la imagen tan importante como la nitidez de los rostros de padres e hijos. Además, hay un trabajo reflexivo de la fotografía sobre su propio estatuto y su puesto en las luchas por la memoria, reduplicado en aquella imagen en la que una foto del famoso collage, en forma de bandera, de innumerables fotos que desfilan en las marchas por el golpe de estado, se proyecta sobre una pared donde una mujer interpone su cuerpo para singularizar una de esas fotografías, seguramente la de su madre. Así, no sólo se tematiza el pasado, sino también, como ya se dijo, las narrativas (visuales) ya existentes de ese pasado.

Pero no sólo en esta reflexividad modernista del procedimiento, sino incluso en los rostros y su poderosísimo montaje, que transita una delgada cornisa entre lo ritual y lo siniestro, ostentan estas imágenes anomalías dramáticas: los padres comparecen con la misma edad que los hijos, testimoniando un desarreglo en las relaciones de transmisión generacional; las imágenes de padres e hijos no siempre respetan una escala común, renunciando así a la pretensión de verosimilitud del encuentro; la proyección de los padres en un haz de luz bidimensional contrasta con el cuerpo del hijo o la hija, tomado en la voluminosidad de sus tres dimensiones; la súbita e innegable similitud que aflora en algunas de las fotos genera, junto a un fugaz reposo cálido de identificación, un siniestro juego de dobles en virtud de cuyo poder fantasmagórico la vida del presente vivifica el pasado perdido, tanto como lo perdido del pasado penetra de muerte a un presente ahora fotográficamente petrificado; las miradas despreocupadas de los padres fotografiados en circunstancias cotidianas o hasta administrativas, contrastan a veces con gestos de hijos que lanzan una mirada inquietante, demandante.

Quizá en las arriesgadas fotos en las que los hijos cruzan sus miradas con los padres se muestre el punto desde donde atar esta multiplicidad de oscilaciones: el acto de un presente que se hace cargo de mirar a los ojos a 
ese pasado. La tensa dialéctica de la mirada de estas fotos viene a mostrar ya no sólo un presente atravesado por la imagen fantasmática del pasado, sino también el gesto activo de construcción de una mirada propia sobre ese pasado.

Nuevamente, montaje: un procedimiento visual reflexivo y un anacronismo temporal inquietante. A través de ellos podemos superar la dicotomía entre diálogo y brecha, entre restitución y denuncia, y a la vez recordamos que la imagen de ese pasado es siempre una construcción activa de un presente que lo convoca, y nunca un mero registro. Nos recuerdan que la memoria ve bajo las formas de la ficción.

\section{Recuerdos inventados}

Esta ficcionalización es eje del segundo ensayo que traemos, que la declara explícitamente desde su propio título, Recuerdos inventados. ${ }^{6}$ Gabriela Bettini nació también en 1977, aunque en Madrid, debido al exilio forzado de su familia argentina, y hoy vive y trabaja allí. Compone sus «Recuerdos inventados» en el año 2003, a partir de fotografías de Antonio Bautista Bettini y Marcelo Gabriel Bettini, abuelo y tío de la autora, desaparecidos en 1976 y 1977, respectivamente. En este ensayo encontramos similitudes con el de Quieto, principalmente la estrategia de la superposición de imágenes fotográficas del pasado y del presente, en la textura crispada de una fotografía que las incluye en un diálogo imposible, «inventado», entre generaciones separadas por el hiato de la desaparición. También Bettini trabaja el estatuto fotográfico no sólo de los procedimientos sino fundamentalmente de su propio objeto, dejando visibles las marcas de la dislocación de temporalidades.

Sin embargo, y ya desde un comienzo, en el ensayo de Bettini resuena un tono más lúdico y sarcástico que en el de Quieto. Un gesto irónico que pareciera acentuar la brecha de un modo más explícito que Quieto. Parece haber más escepticismo acerca de la posibilidad del diálogo, más interés en

6. Se lo puede encontrar en la web: http://www.gabrielabettini.com/proyectos/recuerdosinventados. 
acentuar la artificialidad de un encuentro que antes que inventado es sencillamente imposible. Bettini no sólo realiza un montaje de presente y pasado, sino que la obra final consiste en fotos de sus propios montajes, elevando el bucle reflexivo a un nuevo nivel, pues estos montajes aparecen incluidos en el formato de un álbum familiar que estas imágenes intentarían completar ficcionalmente. Bettini inventa no sólo un presente de los desaparecidos, sino también un pasado del presente de la fotógrafa, desbaratando los órdenes del tiempo y la memoria. Arruina levemente los bordes de las fotos, marca algunas de ellas, las dobla como si hubiesen estado mucho tiempo en alguna billetera, es decir, les inventa una temporalidad irreal, reduplicando su apuesta de ficcionalización.

Una artificialidad llevada casi al ridículo cuando no sólo se superponen las imágenes del pasado con las del presente, sino que se sobreimprime una irreverente teatralización de interacción entre las fotos (colgadas de la pared y con un ostensible marco) y la autora. La reciprocidad de la mirada entre abuelo y nieta en la foto inicial diluye todo posible efecto aurático desde el momento en que sobreactúa la ficticia felicidad de la foto de álbum. Ya no hallamos la sutil dialéctica de la mirada de Quieto, sino una sarcástica pantomima de esa cotidianidad del trato que les fuera violentamente arrebatada. Las miradas son transparentes, los rostros sonrientes, los escenarios familiares (un living), las actividades cotidianas (jugar a las cartas, leer un libro). Como si nada hubiese pasado. Aquí la ostensión de la artificialidad del recuerdo roza el lenguaje de la farsa. Sin embargo, y tensando el arco entre ficción y documento, a diferencia de la materia puramente sensible y corporal de las imágenes de Quieto, aquí Bettini intercala las imágenes familiares con fotos de registros burocrático-policiales, en los que se informa acerca del secuestro, la desaparición y el asesinato de sus familiares. La farsa teatralizada en las imágenes se golpea contra el prosaico registro administrativo de esas muertes.

El choque entre estos dos planos, entre la ficción del artificio visual y la certificación institucional, se resuelve en una de las imágenes más intensas: el abuelo desaparecido, desde la fotografía, y la nieta, desde un presente 
inestable, hacen coincidir sus miradas en las páginas abiertas del Nunca más, ${ }^{7}$ gracias a la misma imagen fotográfica que los reúne.

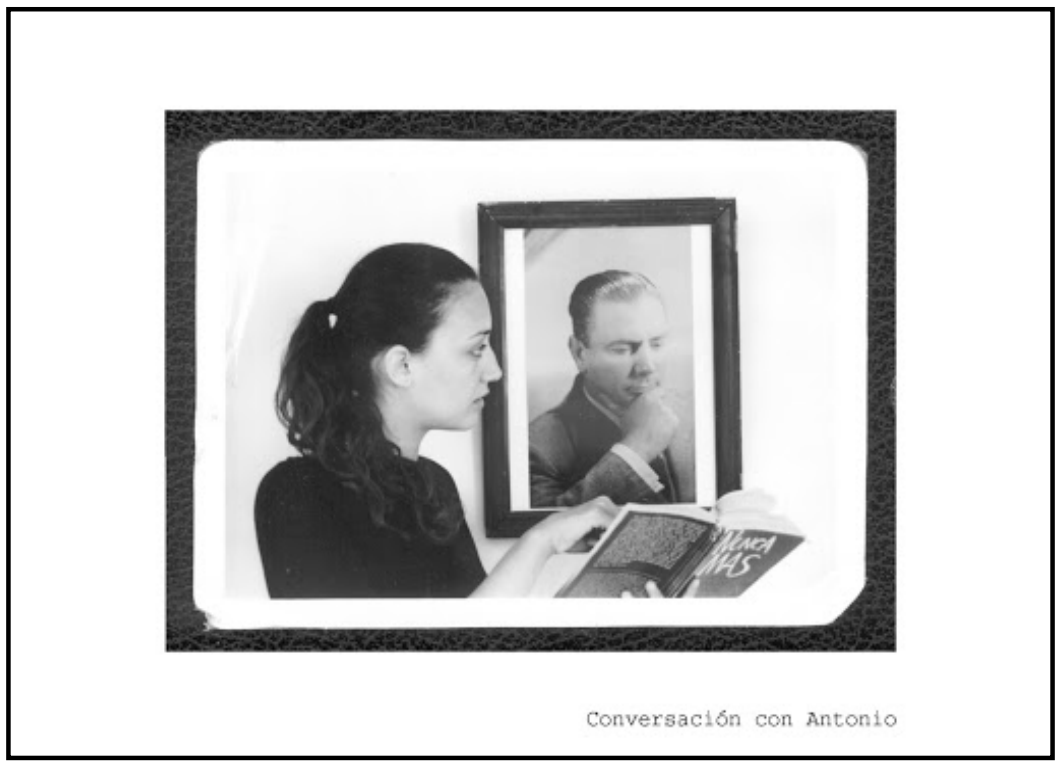

Imagen 2

Imagen tan imposible como poderosa. Una fotografía a tres tiempos, que refuta toda continuidad (el desaparecido lee, ominosamente, su propia muerte) y contamina en el anacronismo visual a las diversas temporalidades entre sí: el tiempo en el que su abuelo aún vivía; el tiempo de la primera memoria del horror y su primer gran relato, que marcó toda una época de la memoria en la Argentina; el tiempo de esta nueva generación que teje su propio relato no sólo con los retazos de los 70 (la foto del abuelo desaparecido), sino también con fragmentos de los relatos sobre los 70 (el ícono del Nunca más). La reflexividad de la imagen se replica en la reflexividad de una memoria que se tematiza a sí misma.

Pero Bettini aun va más lejos. Hay dos fotos en este ensayo en las que, como en el ensayo de Quieto, el presente presta el cuerpo a un pasado cuyo cuerpo fue sustraído, y tramita esa alquimia en la materia sutil de la

7. El libro, elaborado en democracia y publicado en 1984, que recoge el informe oficial sobre lo sucedido en la dictadura militar, y que instaura una primera y muy influyente lectura del terrorismo de estado. 
fotografía, ritual de luz. Sin embargo, Bettini lo realiza desde la tónica sarcástica de su ensayo. Casi como si de muñecos se tratara, retrata los rostros fotografiados de sus parientes (con sus ostensibles marcos), portados sobre los rostros invisibles de cuerpos anónimos. Bettini acorrala al espectador en un clima que oscila entre lo cómico y lo siniestro. En el caso del retrato de su abuelo, una fotografía doméstica del busto del abuelo es portada por un cuerpo que finge por su parte un gesto forzadamente familiar, en una escenografía doméstica de living, sofá y fotos de familia. En el caso de la fotografía de su tío, aparece una ironía mayor, que incluye una de las escasísimas citas del pasado político de los desaparecidos por parte de estas obras. Pero lo hace bajo el signo inequívoco de la parodia. La pertenencia de Marcelo Bettini a la izquierda peronista de los 70 aparece tematizada desde una distancia casi insalvable, que apenas parece recuperar esa militancia en tanto gesto vacío. Un rasgo entendido a veces como despolitizador por lecturas críticas de algunas propuestas visuales representativas de esta nueva generación (paradigmáticamente del film de Albertina Carri Los rubios), muchas veces sin apreciar la singular politicidad inmanente de estas operaciones estéticas.

Por último, la fotografía que cierra este álbum inventado muestra la imagen de una verdadera memoria de utilería. Sentada en una de las playas de Mar del Plata, vemos a la misma fotógrafa junto a una foto familiar que incluye a sus parientes desaparecidos, tomada hace años en el mismo lugar y amplificada a escala natural. Ficcionalización irónica de un modelo de familia burguesa tan imposible como el modelo sacrificial de la familia militante de los 70. Recuerdo de cartón como crítica de un pasado político aún presente como falta.

\section{Ausencias}

Gustavo Germano, nacido en 1964 en Entre Ríos, trabaja hoy en Barcelona. Es hermano de desaparecido, y entre 2006 y 2007 compuso su ensayo Ausencias: Detenidos-Desaparecidos y Asesinados de la Provincia de Entre 
Ríos. 1976-1983. ${ }^{8}$ Este trabajo se conecta con la idea de superponer fotografías del presente y del pasado, con la hipótesis implícita de que no hay la imagen de ese pasado sino imágenes múltiples, fragmentos. Pero además, se liga con esta última idea de la fotografía familiar de Bettini de buscar una fotografía presente que recree una toma del pasado, no sin dejar de mostrar las laceraciones del tránsito, sino precisamente subrayándolas con mayor nitidez. Germano busca el diálogo entre el presente y el pasado desde el punto de vista de la propia toma.

En efecto, también aquí tenemos un montaje de tiempos, aunque no hay estrictamente superposición de imágenes, sino más bien un desdoblamiento o reduplicación. Se separan las imágenes, pero no para apaciguar la mirada sino para duplicar la inquietud y la confusión, devolviéndolas desde la imagen al propio lugar de quien mira, testigo involuntario de una pulsión (visual) de repetición. Presentando dos fotos casi idénticas, Germano recrea, treinta años después, viejas fotos familiares de desaparecidos de su provincia natal. Los mismos lugares, el mismo encuadre, la misma luz, los mismos retratados, los mismos gestos, hasta los mismos muebles o decorados. Sólo dos diferencias clave: el blanco y negro de las fotos originales frente al color de las fotos reconstruidas, que delata el espesor temporal de la propuesta, $y$, crucialmente, la elocuente ausencia de alguno de los retratados.

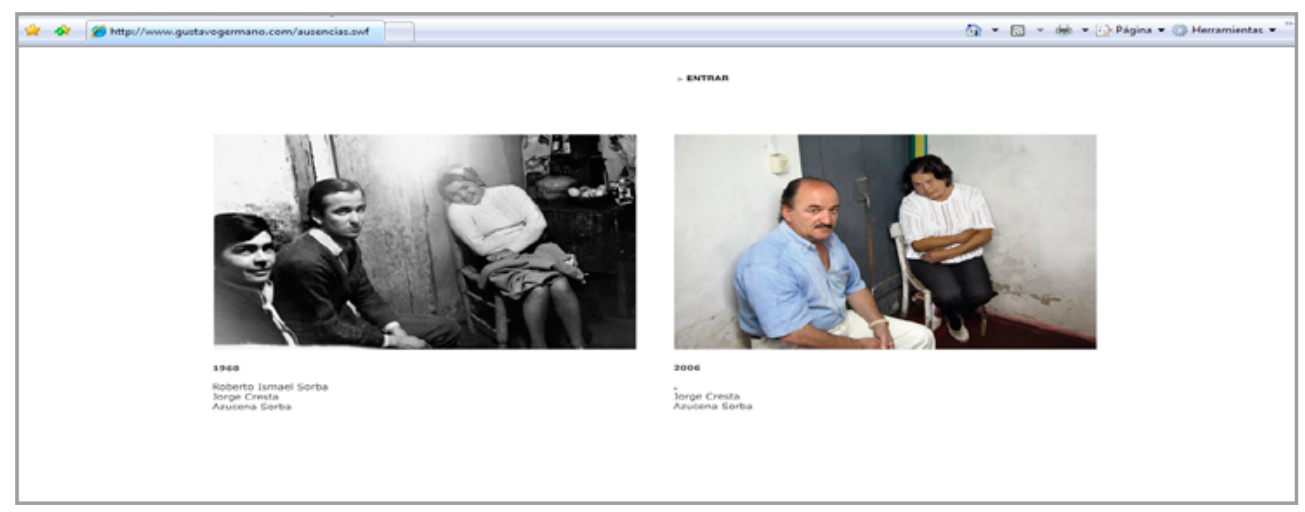

Imagen 3

8. Disponible en la web: http:/www.gustavogermano.com/gallery/ausencias/. 
El tono de este ensayo no es ni poético-ritual ni tampoco sarcástico, como los anteriores, sino más bien austeramente trágico. No interroga la reparación de la ausencia, como Quieto, ni juega irónicamente con ella, como Bettini, sino que simplemente busca evidenciarla, hacerla patente. Pero no llenando un vacío, sino haciéndolo aparecer. La contundencia de estas imágenes pende de la simplicidad de este gesto. Comparte con el de Bettini cierta teatralización de los retratados, que representan la escena del pasado, imitándose a sí mismos en los gestos, las posiciones, los movimientos, para que sobresalga con mayor nitidez la marca indeleble de la diferencia: la ausencia del familiar que ya no está. Como en los ensayos anteriores, aquí la similitud es trabajada desde esas pequeñas diferencias que diluyen el deseo de una unidad o identidad perdidas. El trabajo de identificación es remitido, más bien, a un teatro siniestro de dobles en el que toda similitud es a la vez una distorsión, en que toda familiaridad se torna extraña y la extrañeza se inscribe en los rincones más familiares del álbum, de las habitaciones de la casa, de las escenas cotidianas.

Preside toda la operación el arco que se tiende entre foto y foto, es decir, el tiempo y sus desgarraduras. Ese elemento sutil e inmaterial que sólo puede ser puesto por el espectador, y que en la foto sólo aparece sugerido, que es el tiempo del horror. Ese tiempo del horror no es ni representado ni denegado, ni se lo muestra ni se lo deja de mostrar, sino que es sólo aludido a través de un complejo montaje de imágenes. La materialidad de la composición sólo nos ofrece dos imágenes similares, una junto a otra, con la inocencia de los juegos de «encuentra las diferencias». Lo que completa el sentido es sólo la posición del sujeto receptor que repone la temporalidad aludida por el vacío existente entre una y otra foto. El horror sólo se muestra en la invisible textura de la memoria del que contempla estas imágenes.

\section{Montajes}

Estas imágenes fueron elaboradas entre 1999 y 2007, es decir, en una etapa en la que se tramitaba ya no sólo la relación con el pasado traumático (un relato, una imagen del horror), sino además la relación con los debates sobre la memoria de las últimas tres décadas (un relato del relato, una ima- 
gen de la imagen). Tanto más en el caso de las voces de los miembros de una generación que no vivió ese pasado, y que no lo conoció sino a través de esas polémicas por la memoria. La novedad de estos «nuevos testigos» pasa justamente por la necesidad de dar cuenta a la vez del pasado y de los debates sobre ese pasado. En estos ensayos fotográficos, el objeto no es ya sólo el pasado, sino fundamentalmente la relación de ese pasado con un presente que se siente interpelado por él. Ya no sólo lo sucedido, sino eminentemente los modos de recordarlo.

Desde este rasgo genérico, estos ensayos responden al doble debate con el que se inició este trabajo: representan la emergencia de una nueva voz en la constelación de la memoria y un posicionamiento en el debate sobre la representación. Estos ensayos se posicionan ante este doble debate planteando dos grandes desórdenes: un desarreglo temporal y un trastorno visual. Ambos desajustes redundan en una problematización extrema de la cuestión de la identidad (en lo diacrónico-temporal en un caso, en lo sincrónico-visual en el otro).

El desarreglo temporal remite, como lo dijimos al comienzo, a una desorganización de la estructura lineal del tiempo implícita en los historicismos pedagogizantes tanto de la memoria de los 80 como de la memoria de los ex militantes (cuyo auge situamos a mediados de los 90). «Ni en el pasado, ni en el presente, estas imágenes se colocan, de este modo, en un entre tiempos, más precisamente, en el abismo que resulta de la convivencia disruptiva entre cuerpos ausentes y otros presentes» (Blejmar, 2009, p. 205). Contra toda teleología, sea republicana o revolucionaria, estas imágenes ensayan la experiencia de una temporalidad emancipada de los mandatos del tiempo cronológico, a saber, el imperio de la continuidad e irreversibilidad, y de la idealización del dolor. Ni continuidad, ni irreversibilidad, ni escamoteo de las víctimas, estas imágenes habilitan la vivencia del tiempo de la memoria, es decir, del tiempo del anacronismo, del síntoma y de lo siniestro. Frente a la continuidad, se afirman en la fractura y discontinuidad de tiempos que se citan anacrónicamente; frente a la irreversibilidad, sostienen la irrupción sintomática de un suelo de experiencias traumáticamente olvidado; frente a las idealizaciones forzadas, exponen lo extraño y amenazante que contamina hasta lo íntimo de los álbumes de familia. 
El desarreglo visual remite, como también se planteó al comienzo, a un más allá de la polémica «representable vs. irrepresentable». Aquí la clave está en una relación más libre con el referente, e incluso a veces, en una decidida crítica al estatuto representacional y la asunción de la fotografía como aventura eminentemente ficcional. Aquí tocamos un último punto de mucha importancia. Pues es casi un lugar común en muchos análisis sobre la relación entre fotografía y desaparición el énfasis en la potencia testificadora, certificadora, indicial, deíctica, de la fotografía, el «esto ha sido». ${ }^{9}$ Según estas lecturas, las fotos de desaparecidos tendrían la fuerza de denunciar la desaparición, mostrando la presencia inocultable de lo que ha sido, enfrentando la evidencia de su presencia pasada al horror de su forzada desaparición. ${ }^{10}$ Sin embargo, un rasgo clave de estas fotos es precisamente la dislocación del estatuto documental de la fotografías de desaparecidos. Sería un exceso hablar de mera ficcionalización y de un borramiento total del carácter indicial de la foto. De hecho, la tensión entre documento y ficción, entre registro y producción, es una de las principales riquezas de estas imágenes (y en general del procedimiento del montaje como tal, y del ambiguo estatuto de lo real en sus realizaciones). ${ }^{11}$ Pero sin duda, estamos muy lejos del deíctico barthesiano: estamos casi en las antípodas del «esto ha sido». El estatuto marcadamente ficcional de estas nuevas voces de la memoria en la Argentina ha sido a veces criticado en términos de recaídas intimistas, como "giro subjetivo», como adecuamiento funcional a nuestros tiempos pos-políticos de regreso a la módica privacidad, como una incapacidad para pensar el legado de los 70 como legado político, etc. ${ }^{12}$ Asimismo, los defensores del carácter indicial de las fotos de desaparecidos las han contrapuesto al borrado del referente en las imágenes digitales, como un modo de borrado de lo real, como una complicidad con una nueva forma de desaparición. ${ }^{13}$ Sin embargo, creo que

9. Según cierta lectura usual de Barthes, 2005.

10. Por ejemplo: Richard, 2000; Déotte, 2000; también, en parte, Da Silva Catela, 2009.

11. Intentamos una lectura de este inestable equilibrio entre equilibrio y ficción en García, 2013.

12. Representativo de este tipo de críticas es Sarlo, 2005.

13. Véase Déotte, 2000; y Richard, 2000. 
ni la política ni lo real se borran de estas fotos, y sólo se pueden plantear tales críticas desde parámetros estético-políticos anclados en el pasado.

La verdad de estas fotos se juega más allá de la dualidad documento/ ficción o analógico/digital. «El pasado, aun en sus puntos más dolorosos, es rehecho como fábula, pero no a modo de falsificación o invento, sino de creación, único resorte de la memoria» (Amado, 2009, p. 192). Con «ficción» no se alude a una suerte de irrealidad, sino a un desarreglo de lo real mismo, y de las formas de referirlo. «Ficción» como salida al atolladero siguiente: ¿cómo pretender «representar» aquellos acontecimientos que refutaron el régimen moderno de la representación? Asimismo, estos jóvenes artistas formados en la era digital, que por sí misma cuestiona la pulsión testificadora que la imagen fotográfica tenía para Barthes, aunque no utilicen procedimientos digitales, trabajan en estos ensayos con un material más sutil que el referente: el material es la fotografía misma, o mejor aún, es el tramado sutil de la memoria. Imágenes de imágenes, son una indagación autorreflexiva del estatuto testimonial del documento. Parecen decirnos que si el documento es fundamental no lo es principalmente por su fuerza referencial, sino como elemento en una construcción que lo excede ampliamente como indicio de un dato empírico. Lo cual no significa que lo real se diluya en un flujo acelerado de circulación digital-mercantil de imágenes post-analógicas, sino que lo real deja de pensarse desde la dimensión semántica de la relación imagen-objeto, y pasa a ser pensado desde la sintaxis fracturada de la memoria: mostrar este real traumático sería, más que reponer la presencia de una ausencia, retramar una sintaxis (visual, en este caso) en la que el vacio de la ausencia tenga finalmente su propio lugar. Este desarreglo de la sintaxis del tiempo y de la imagen sería, entonces, la promesa estético-política de estas imágenes.

Trastorno del tiempo y de la imagen: éstos son los rasgos fundamentales de la politicidad de estas obras, que sólo puede pasarle desapercibida a aquellas lecturas ancladas en los modos de lo político de los 70. Politicidad de la propia forma-montaje: montaje visual que activa una crítica de la representación y propone la creación de acontecimientos visuales para pensar la historia. Montaje histórico que propone un desarreglo temporal orientado críticamente contra todas las formas de historicismo con que la militancia tradicional se desentendió del lado oscuro de su propia acción. Una política 
de la imagen y una política del tiempo de una generación en la que podrían alumbrarse las matrices de nuevas formas de lo político. Una guerra de posiciones cultural y visual en la que se va gestando una nueva voz. Como ha señalado Ana Amado: «Una generación que marca las diferencias, elude las fórmulas de exaltación épica de los protagonistas (o de la insurgencia) de aquella historia y ejercita su pensamiento crítico, su rebeldía, con la opción de una vanguardia estética que continúa y replica en su terreno (...) la vanguardia política de la que formaron parte sus padres y su generación» (Amado, 2009, p. 197).

\section{Referencias}

Amado, A. (2009): La imagen justa, Colihue, Buenos Aires.

Barthes, R. (2005): La cámara lúcida. Nota sobre la fotografia, Paidós, Buenos Aires.

BLEJMAR, J. (2009): «En las ruinas de la historia. Fotografía, filiación y desaparición», El río sin orillas. Revista de filosofía, cultura y política, $\mathrm{n}^{\circ} 2$.

Blejmar, J.; N. Fotuny y L. I. García (eds.) (2013): Instantáneas de la memoria. Fotografia y dictadura en Argentina y América Latina, Libraria, Buenos Aires.

Brodsky, M. (comp.) (2005): Memoria en construcción: el debate sobre la ESMA, La Marca Editora, Buenos Aires.

Casullo, N. (2009): «Memoria y revolución», Pensamiento de los confines, $n^{\circ} 23 / 24$.

Da Silva Catela, L. (2009): "Lo invisible revelado. El uso de fotografías como (re) presentación de la desaparición de personas en la Argentina», en Feld, C. y J. Stites Mor (comps.): El pasado que miramos. Memoria e imagen ante la historia reciente, Paidós, Buenos Aires.

Didi-Huberman, G. (2004): Imágenes pese a todo. Memoria visual del Holocausto, Paidós, Barcelona.

DÉotTe, J. L. (2000): «El arte en la época de la desaparición», en Richard, N. (ed.): Politicas y estéticas de la memoria, Cuarto Propio, Santiago de Chile.

Fortuny, N. (2009), «La foto que le falta al álbum. Memoria familiar, desaparición y reconstrucción fotográfica», XII Jornadas Nacionales de 
Investigadores en Comunicación, en <http://www.redcomunicacion.org/ memorias/index.php>

García, L. I. (2008): «Arqueologías de un presente político-cultural», Pensamiento de los confines, $\mathrm{n}^{\circ} 22$.

— (2009): «Imágenes de ningún lugar. Sobre la representación del horror en la Argentina», Nombres. Revista de Filosofía, $\mathrm{n}^{\circ} 23$.

- (2013): «Espectros. Fotografía y desaparición en la Argentina», en Papel Máquina. Revista de cultura, $\mathrm{n}^{\circ} 8$, Santiago de Chile.

Hirsch, M. (1997): Family Frames. Photography, Narrative and Postmemory, Harvard University Press, Massachussets.

Jelin, E. y A. Longoni (eds.) (2005): Escrituras, imágenes y escenarios ante la represión, Siglo XXI, Madrid y Buenos Aires.

Kaufman, A. (2005): «Setentismo y memoria», Pensamiento de los confines, $\mathrm{n}^{\circ} 16$.

Longoni, A. (2011): «Apenas, nada menos», en Quieto, L., Arqueología de la ausencia, Casa Nova, Buenos Aires.

Lorenzano, S. y R. Buchenhorst (2007): Políticas de la memoria. Tensiones en la palabra y la imagen, Gorla, Buenos Aires.

Oberti, A. y Pittaluga, R. (2006): Memorias en montaje. Escrituras de la militancia y pensamientos sobre la historia, El cielo por asalto, Buenos Aires.

Pittaluga, R. (2007): «Miradas sobre el pasado reciente argentino. Las escrituras en torno a la militancia setentista (1983-2005)», en FRANCO, M. y F. Levín (comps.): Historia reciente. Perspectivas y desafios para un campo en construcción, Paidós, Buenos Aires.

Richard, N. (2000): «Imagen-recuerdo y borraduras», en id. (ed.): Políticas y estéticas de la memoria, Cuarto Propio, Santiago de Chile.

SARLo, B. (2005): Tiempo pasado. Cultura de la memoria y giro subjetivo. Una discusión, Siglo XXI, Buenos Aires. 